\title{
Designing, Planning \& Implementation of IT Infrastructure \& Security for A Brokerage House
}

\author{
Muhammad Tahir ${ }^{1}$, Asim Rafiq ${ }^{2}$, Danish Hassan ${ }^{3}$
}

\begin{abstract}
M-Commerce is widely known as wireless network technology, use as the essential means of communication for business transactions. Mobile commerce is seen as an augmentation of E-commerce empowered by cell phones. Transactions either indirectly or directly carried out or supported through mobile phones. ABC Brokerage House is the pioneer in Online Trading Services. In online trade, customers can trade using the online trade software and website. Before switching users, from traditional trading system to mobile trading system, the weaknesses of infrastructure, security breaches, and risk factors should be considered carefully. The infrastructure solution should be designed with respect to interoperability, security, scalability, non-repudiation of ABC Brokerage House on the behalf of best practices for Mobile Commerce Trading System. The solution has its distributed nature and is a suitable architecture for managing business processes of ABC Stock Brokerage House. The solution is well planned, designed and it is in accordance with ISO recommendation. The solution provides more flexibility and also provides redundancy by using clustering of database server. The proposed solution provides more flexibility and also provides redundancy plan and clustering of database server. This solution also switches $\mathrm{ABC}$ Brokerage House infrastructure to the real world infrastructure by removing risk factors and implementing the latest technologies.
\end{abstract}

Index Terms - M-Commerce, Stock exchange, Brokerage house, Stock agent, Stock trader, Risk analysis.

\section{INTRODUCTION}

As of late, web suppliers have turned out to be more intrigued in supporting client activities in the portable environment with the quick improvement of communication technologies, for example, $2 \mathrm{G}$ to $3 \mathrm{G}$ with more steady or speedier transmission rates, different sorts of portable applications have turned out to be famous [1]. Mobile brokerage is a financial self-service channel that extends the broker's reach into a customer base. For consumers, it is a convenient, simple, ubiquitous, trusted and 'always on' electronic interface to the stock for brokerage services on a mobile phone. For Stock Brokerage House, it is a platform with the highest operational and security standards that can be 'plugged into' at low cost. This immediately opens a path to the personal device of millions of consumers.

M-commerce presents some unique characteristics and features that can provide customers with added values and benefits, such as anytime and anywhere access, the capability to pinpoint mobile devices' locations for personalization and localization, and the functionality to access information at the point of need. M-Commerce presents a new channel/medium for commerce.

The central theme of this study is to investigate and explore emerging technologies, and challenges for Brokerage House. For mobile commerce to end up distinctly a feasible method for doing business and to increase across the board appropriation, it is essential that dealers comprehend and concentrate on the "values" of M-Business from the clients' points of view; that is, what are clients' general appraisals of mobile commerce, and what do clients anticipate from mobile commerce. Mobile commerce implementation both the users and the business faces the problems. The type and the need of a user are the points to be considered by the application providers [2].

M-Commerce services are ultimately packaged, there will be a need to ensure the security and integrity of the underlying infrastructure. Increase in technical protection and isolation of internal systems and of the network itself will be necessary in view of the greater exposure through public network access. There are internal, external threats and vulnerabilities in the existing infrastructure of information technology of the brokerage houses connected to the Karachi Stock Exchange Limited.

The objective of the study is to design a flexible infrastructure to accommodate the current requirement by utilizing the technology at the maximum level and needs for potential demand or reconfiguration of facilities employing sound planning principles and infrastructure design of information technology. Mobile brokerage is a two-way channel with proactive marketing potential and it complements a distribution channel that puts the "anywhere" in brokerage and connection to the ecosystem, place brokerages in the connected commerce, story. Highly personalized service enables customer retention and nurturing and the innovation in the services that differentiates from the competitors.

\section{LITERATURE REVIEW}

E-Commerce embryonic is as a major mode of doing trade when it comes to share market and brokerage house. The increasing use of technology has endowed clients with an opportunity to keep track of their sales and purchase and major

\footnotetext{
${ }^{1}$ Associate Professor, Department of Computer Engineering, Sir Syed University of Engineering \& Technology, Karachi, Pakistan. tahirfattani@ gmail.com

${ }^{2}$ Lecturer, Department of Computer Science, Sir Syed University of Engineering \& Technology, Karachi, Pakistan. asim_r83@ hotmail.com

${ }^{3}$ Lecturer, Computer Engineering Department, Sir Syed University of Engineering \& Technology, Karachi, Pakistan. sdhraza@ hotmail.com
} 
activities of every day's business. The paper introduces the concept of 'Glocalization' that allows for the creation of products and services locally that suite the needs of clients globally. As the concept of M-Commerce evolves, an array of services are being introduced, mobile brokerage is one of them. They allow for instant selling and purchasing of shares on mobile devices without using the conventional methods [3]. M-Commerce offer customers to connect to ABC Brokerage house from any virtual location at any time. This comes as a value added service for customers. Researchers have presented four different business models for adapting M-Commerce in brokerage industry: Basic model, Incentive model, Preference model and Elastic model.

The Basic model best suites the needs of small investors are providing them with real-time stocks, allow them to receive instant updates via SMS and view their portfolios. Incentive model is rather expensive and designed for remunerative investors, who are being offered reduced commission rates. This model involves complex calculations, as reduced rates are offered depending upon the category of investor.The Preference model supports ubiquity for active investors. The customers are permitted to connect via a wide range of devices from any physical location and enjoy all benefits in Incentive model. Elastic model is an amalgamation of using independent platforms and bundled pricing. This requires an extra effort at the end of developers, to cope up with high quality solutions for enormously complex calculations. Customer focus and technical innovation is the key to success in Mobile Brokerage Industry [4]. M-Commerce is widely known as wireless network technology, use as the essential means of communication for business transactions. Mobile commerce is seen as an augmentation of E-Commerce empowered by cell phones. Transactions either indirectly or directly carried out or supported through mobile phones [5]. Transactions performed using wireless network devices for communication known as Mobile commerce: Equity trading, goods ordering, chatting and transfer of funds [6].

Mobile commerce applications include two significant characteristics, broad reach \& mobility. Mobility infers convenience, for example, performs business transactions using cell phones in real time. Most researchers demonstrate that users can be accessed through mobile application [7-9]. India is facing the emerging phase of mobile commerce and it is intricate to familiarize. Use of mobile commerce not only to do call, but it is also offers shopping, to access web content and chatting as well [10]. A study related to a concise description of an association between mobile and electronic commerce, wireless mobile technologies, essentials of MCommerce and E-Commerce, define what can be achieved through mobile commerce and types of mobile commerce applications [11]. Localization, instant connectivity, mobility factor, personalization factor and immediacy are the key factors for the growth of mobile commerce in India [12].

Logical grouping of issues and obstacles of mobile commerce includes (1) security (2) legal and regulatory (3) marketing challenges (4) high cost of wireless transactions (5) mobile wireless infrastructures (6) trust (7) ethical and privacy concerns (8) mobile device limitations (9) connection stability (10) uncertainties of evolving industries [13]. Issues related to the physical security, is safe access. The danger, of information access over wireless networks by unauthorized users [14], with those users utilizing their own particular gadgets or stolen gadgets, is a security risk [15]. The security over wireless networks of information is a concern [16]. Wireless information broadcast is more susceptible to snooping [17], [18]. Trust is concerned with security, but trust is a business and a psychological issue than a technical one. Potential users of mobile commerce, considers the mobile commerce to be a safe environment [19]. Significant factors to mobile shopping are trust and security, so customer trust is must for mobile players [20]. Low speed, complex navigation, high cost, strenuous typing through phone keypad and unreliable service are the significant factors of dissatisfaction [21], [22]. Means of communication are significant factors for users as reliability is concerned [23].

\section{RESEARCH METHODOLOGY}

In this study, we will explain the case of the $\mathrm{ABC}$ Brokerage House a corporate member of the Karachi Stock Exchange (Guarantee) Limited (KSE), the Lahore Stock Exchange (Guarantee) Limited (LSE) and Islamabad Stock Exchange (Guarantee) Limited (ISE). The ABC Brokerage House started its operation in 1994. ABC is a dominant brokerage house in Pakistan, offering wide range of services across the region. Services include equity research, financial advisory, economic analysis and investment management services and it has largest customer base round 6000 clients. We will discuss the existing information technology infrastructure of the $\mathrm{ABC}$ brokerage house and endeavor to identify the loopholes in the existing infrastructure and proposed the solution to avoid security risk. Core services offered by ABC Brokerage House include: Equity Brokerage, Corporate Finance and Equity Research.

\section{A. Equity Brokerage}

ABC Brokerage House benefits more than 100 institutional and valued customers spread more than a few areas including: Public and Private Sector Corporations, International Equity Funds, Commercial and Investment Banks, Leasing Companies and Modarabas, Development Finance Institutions, Corporate Provident and Pension Funds, International Equity Funds and Mutual Funds and Investment Companies [23].

\section{B. Conceptual View, of Wireless Web}

Conceptual view of wireless web can be described as:

- Access from web browser to the web server over wired internet.

- Access to web contents of HTML/ XML files.

- Access to non-web content through a web gateway.

- Access from cellular phone over a wireless network.

- Access from the wireless gateway to a web server over wired internet. 


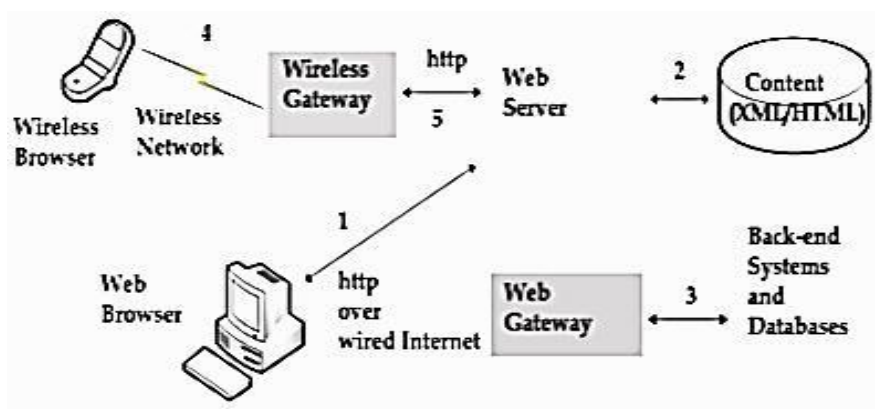

Fig. 1: Conceptual View of Wireless Web ABC Brokerage House

\section{Conceptual Frame Work}

The mobile commerce applications are defined in Table I:

Table I: Mobile Commerce Application Framework

\begin{tabular}{|c|c|}
\hline $\begin{array}{c}\text { Mobile Commerce } \\
\text { Application }\end{array}$ & $\begin{array}{c}\text { Example of Service } \\
\text { Offered }\end{array}$ \\
\hline Mobile Brokerage & $\begin{array}{ll}\checkmark & \text { Mobile Accounting } \\
\checkmark & \text { Mobile Brokerage } \\
\checkmark & \text { Mobile Financial } \\
& \text { Information }\end{array}$ \\
\hline Mobile Entertainment & $\begin{array}{ll}\checkmark & \text { Mobile } \\
\checkmark & \text { Download of Music and } \\
& \text { Ring Tones } \\
\checkmark & \text { Download of Videos and } \\
& \text { Digital Images } \\
\checkmark & \text { Location-based } \\
& \text { Entertainment Services } \\
\checkmark & \text { Load Balancing shall be } \\
& \text { used for online Clients }\end{array}$ \\
\hline Mobile Information Services & $\begin{array}{l}\checkmark \text { Travel, Information } \\
\checkmark \text { Tracking Services } \\
\text { (Persons and Objects) } \\
\checkmark \text { Mobile Search Engines } \\
\checkmark \text { Mobile Directories } \\
\checkmark \text { Mobile Office }\end{array}$ \\
\hline Mobile Marketing & $\begin{array}{l}\checkmark \text { Mobile Couponing } \\
\checkmark \text { Direct (context-sensitive) } \\
\text { Marketing } \\
\checkmark \text { Organization of Mobile } \\
\text { Events } \\
\checkmark \text { Mobile Newsletters }\end{array}$ \\
\hline Mobile Shopping & $\begin{array}{l}\checkmark \text { Mobile Purchasing of } \\
\text { Goods and Services }\end{array}$ \\
\hline Mobile Ticketing & $\begin{array}{l}\checkmark \checkmark \text { Public Transport } \\
\checkmark \text { Sports and Cultural Events } \\
\checkmark \text { Air and Rail Traffic } \\
\checkmark \text { Mobile Parking } \\
\end{array}$ \\
\hline Telematics Services & $\begin{array}{l}\checkmark \text { Remote Diagnosis and } \\
\text { Maintenance of Vehicles } \\
\checkmark \text { Navigation Services } \\
\checkmark \text { Vehicle Tracking and } \\
\text { Theft Protection } \\
\checkmark \text { Emergency Services }\end{array}$ \\
\hline
\end{tabular}

\section{Business Case Clarity}

Most important questions for Pakistani market is, who pays for the technology and marketing, servicing the combined customer and who gets to keep the majority share of the revenues. The user uses Online Mobile Trading System (OMTS) Application to start process to communicate with the Mobile Trading Application Server (MTAS) and then communicate with the Message and Feed Server to receive stock market feed. Message and Feed Server receive requests from Online Trading System Application on behalf of a user and forward it to Database Server to verify User ID and Password. If connection of Online Trading System Application interrupts with Message Server then Online Trading System Application should retry to connect or troubleshoot internet problem at their end.

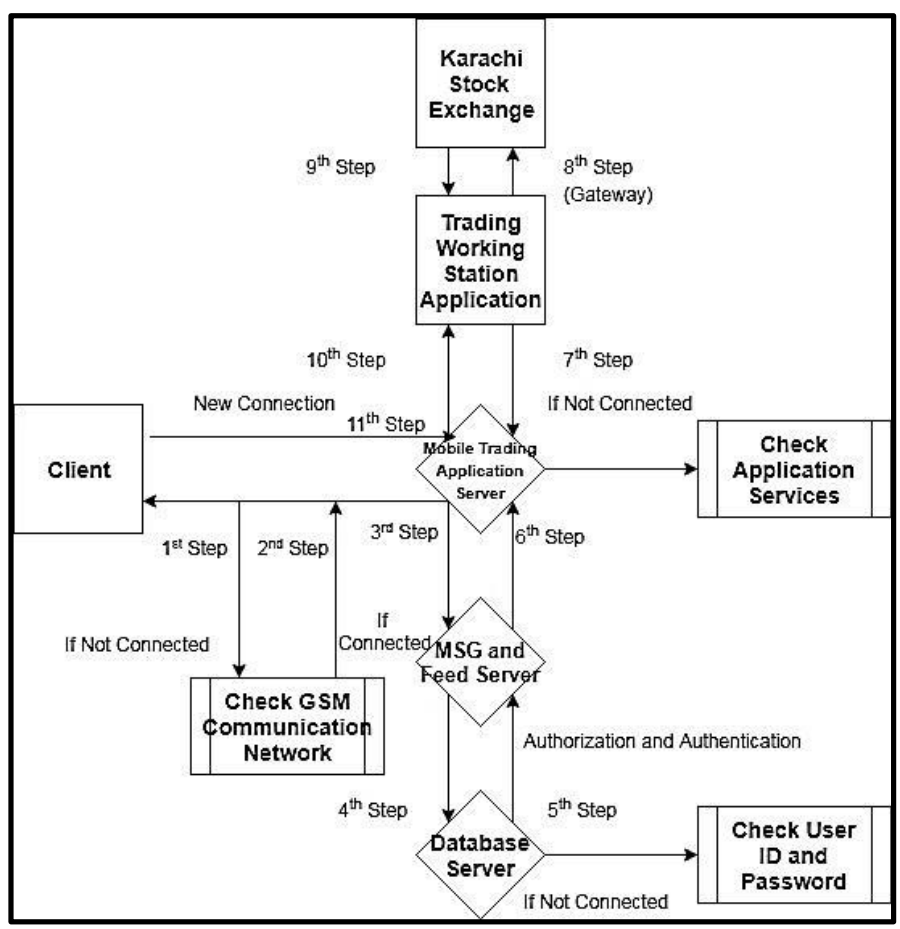

Fig. 2: Workflow of ABC Brokerage House

Database server is used to verify User ID and Password for the user. When Database Server verifies User ID and Password then database sent back a user request to Message Server. If connection of Online Trading System Application interrupts with Database Server then Online Trading System Application should retry to connect or troubleshoot internet problem at their end. Message and Feed Server receives back request after verification from Database Server. Message and Feed Servers enable user to receive feeds of the stock market. Message server only receives messages of stock market through Gateway. While Feed Server receives feed from KSE and send it to end users. If connection of Online Trading System Application interrupts with Feed Server then Online Trading System Application should retry to connect or troubleshoot internet problem at their end (see Fig. 2). Trading working station application is the only way to connect to Karachi Stock Exchange. Trading working station application enables user to make a transaction to Karachi Stock Exchange. Message and Feed server communicates with Karachi Stock Exchange through this application.

\section{E. Existing Technical Infrastructure}

Existing technical infrastructure is divided into two parts: SMS Brokerage and Mobile Trading.

SMS Server is a technology-enabled service offering from stock brokerage house to its customers, permitting them to 
operate selected brokerage services over their mobile phones using SMS messaging. SMS brokerage services are operated using both push and pull messages. Push messages are those that the brokerage house chooses to send out to a customer's mobile phone, without the customer initiating a request for the information. Typically push messages could be either Mobile marketing messages or messages alerting an event which happens in the customer's account, such as a purchasing and selling of shares from trading workstation application.

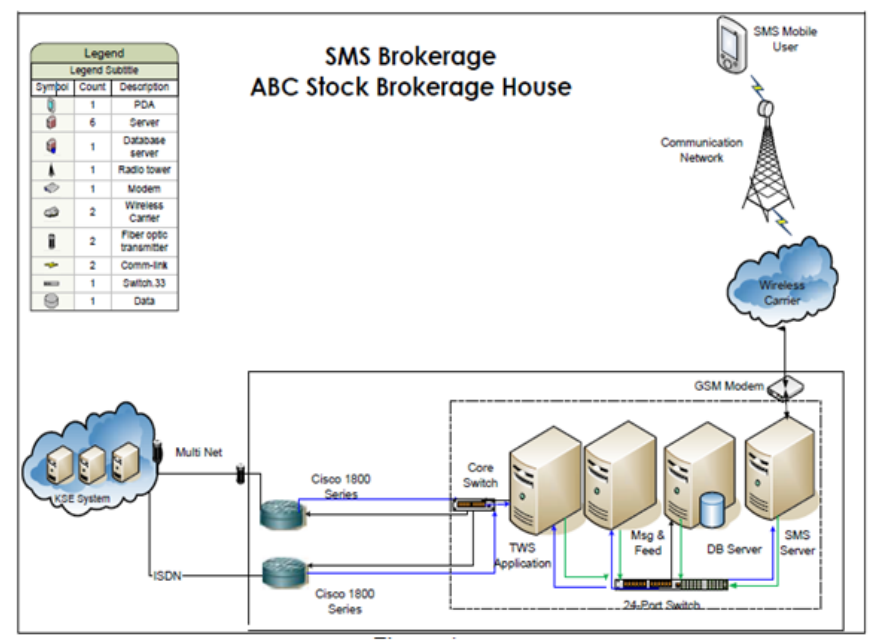

Fig. 3: SMS Brokerage Workflow

In ABC Brokerage House Scenario the DB Server is used to maintain the data of all the clients and keep all the logs of the client's exposure history and portfolio. DB Server also has all authorized client's information whoever is logged into the company's network for trading or viewing the rate on the website. DB Server will maintain the login ID and password of clients and the database of the application running on the server as well at the client side. The DB Server keeps all the history of each and every client's order which enables the company's management to keep track of order history of each and every client (see Fig. 3).

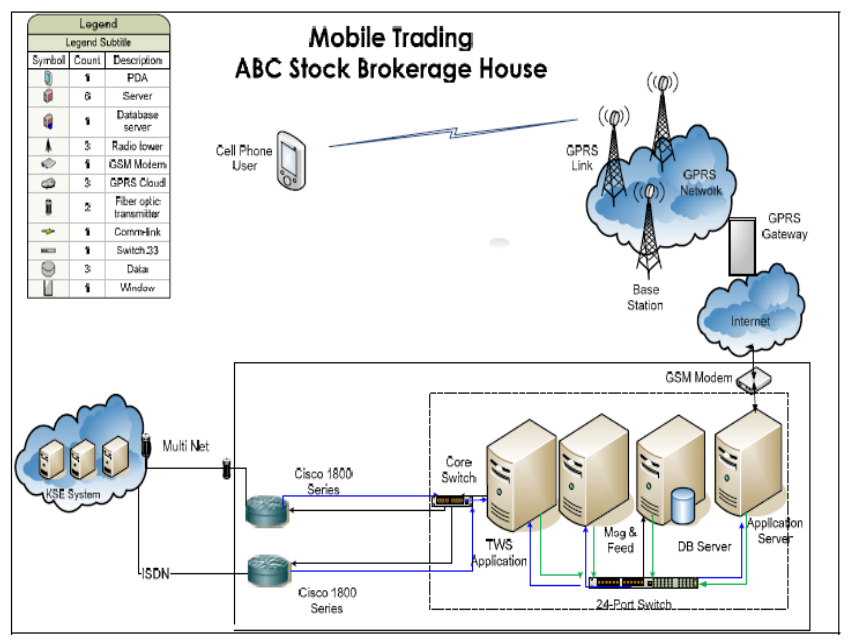

Fig. 4: Mobile Trading Workflow
Mobile technology is a technology-enabled service offering from stock brokerage house to its customers, permitting them to operate selected brokerage services over their mobile phones. Communication links are same as discussed in a previous scenario. The ABC Brokerage House does not need any Database Server for this purpose. In this scenario client installs mobile trading application on their cell phone.

First Client connects to the internet and then connects to the application server GSM, which is placed on the premises of the ABC Brokerage House. The client gets rates on their cell phone (see Fig. 4). If the client has viewed only terminal, then he/she can only view rate of a particular script. If the client has trading authority, then he/she can trade on Karachi Stock Exchange.

\section{RESULTS}

\section{A. Risk Analysis}

The Risk Assessment covered all the internal as well as external risks, threats and vulnerabilities of IT infrastructure in the existing infrastructure of ABC Brokerage House:

i. $\quad$ Very large customer base in a developing market with emerging infrastructure price and cost sensitive.

ii. Large customer base, a portion of which is affluent, in a developed marketplace with developed infrastructure.

iii. Main interfaces are exposed to outside.

iv. Integrity and confidentiality of subscriber data not granted.

v. Attacks from internal and external sources against services and infrastructure.

vi. Service outages lead to loss of revenue and reputation.

\section{B. Risks in Networks in the Existing Infrastructure}

i. Local network and KATS network are on the same switch.

ii. VLANs are not configured.

iii. No auto shifting on the router for Point to Point KSE connectivity.

iv. No auto shifting to the internet.

\section{Risks in Media with the Existing Infrastructure}

i. No radio $\mathrm{P} 2 \mathrm{P}$ connectivity from $\mathrm{KSE}$ to $\mathrm{ABC}$ Brokerage House.

ii. No backup of Fiber link is available.

iii. No backup of GSM Network

\section{Risks in Hardware in the Existing Infrastructure}

i. A firewall is not present at ABC Brokerage House.

ii. All ports are open.

iii. At the same time the only single router is connected to KATS terminal.

iv. Risks in Application in the existing Infrastructure are given below:

○ No authentication for view only users.

- No encryption of data.

- No redundancy of Database server \& Application Server.

- Application files may corrupt. 


\section{E. Recommendation for Risk Mitigation}

To limit or control risk the following should be considered:

i. Risk controlling is the most common Risk Mitigation strategy. Companies adopt some proactive approaches to mitigate the unforeseen Risk.

ii. 2-way text messaging-based services including balance inquiries, simple statements and, alerts.

iii. Low cost delivery of entry level mobile brokerage opens a service to the entire base as well as giving access to the additional segment of mobile deviceequipped; the under-served and un-brokerage.

iv. Layered defence.

v. Customer data should be highly protected.

vi. Clear access control between domains.

vii. Dedicated protection of, publicly reachable services interfaces.

viii. To stop broadcasting from Karachi Stock Exchange the VLAN will configured to manageable switch.

ix. Risk limitations include installing firewalls to keep networks safe by publishing desired ports and putting all servers in the DMZ.

x. Risk limitations included data should be encrypted and only authorize person can access that data.

xi. Risk Limitations include proper backup of critical server machine and hardware.

xii. Risk limitations include creating proper backups to keep data safe.

\section{F. Proposed Solution}

i. Radio Link is another way to communicate with Karachi Stock Exchange.

ii. In $\mathrm{ABC}$ Brokerage House Scenario the Radio link is the main link from KSE. For reliable and secure P2P Connection is used to get the KATS feed from KSE. Radio link is the main link from KSE.

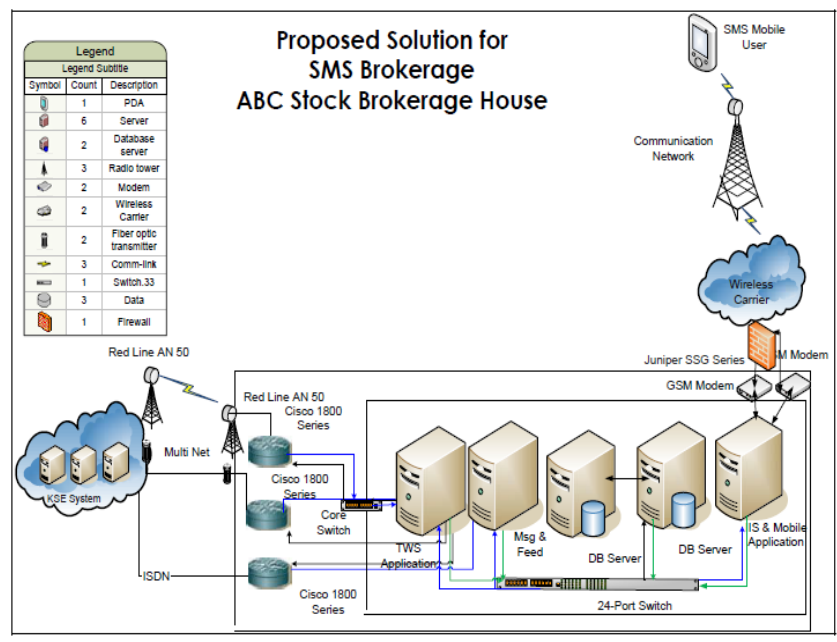

Fig. 4: SMS Brokerage (After Risk Mitigation)

\section{G. Comparison between Existing and Proposed Infrastructure}

i. Multinet Fiber is the backup link and ISDN is the second backup.

ii. We introduce another DB Server for the same purpose. iii. Basically, we created the Active Data Guard between database servers which perform the same task as clustering does.

iv. In Oracle $11 \mathrm{~g}$ Active data guard feature makes it possible to query a physical standby database while Redo Apply is active.

v. Active Data Guard is a simple, high performance solution that maintains an up-to-date replica used to offload resource-intensive queries, reporting and backup operations from the production database.

vi. A physical standby database can be open for readonly access while Redo Apply is active. This capability is known as Real time Query or Active

vii. Data Guard. To enable and use this functionality, it required a separate license.

viii. Now ABC Brokerage House has two GSM connections from different providers. All traffic will be forwarded outside the premises will be routed via Firewall.

ix. The proposed Juniper SSG firewall is used to secure all servers. Put all servers in the DMZ. Block all ports except the desired ports.

x. To make separate ABC Brokerage House's network from the Karachi Stock Exchange's network, create VLANs on the switches.

xi. The benefit of creating VLANs is to stop extra broadcasting generated from Karachi Stock Exchange.

xii. In this scenario client only receives SMS alters what he/she is trading on a market.

The comparison between Existing and Proposed Modified Mobile Commerce Application Framework is briefly illustrated in Table II:

Table II: Existing and Proposed Modified Mobile Commerce Application Framework

\begin{tabular}{|l|l|}
\hline \multicolumn{1}{|c|}{ Existing Infrastructure } & \multicolumn{1}{c|}{ Proposed Infrastructure } \\
\hline No backup of fiber link & Radio link use for backup \\
\hline $\begin{array}{l}\text { The only single P2P link is } \\
\text { working at the same time. }\end{array}$ & Each link work separately. \\
\hline No firewall is present & $\begin{array}{l}\text { A firewall is there for } \\
\text { security. }\end{array}$ \\
\hline All servers are insecure. & $\begin{array}{l}\text { All servers shall be placed in } \\
\text { the DMZ. }\end{array}$ \\
\hline $\begin{array}{l}\text { All ports of the server are } \\
\text { open. }\end{array}$ & Only desired ports are open. \\
\hline Manual shifting of P2P. & Automatic shifting of P2P. \\
\hline $\begin{array}{l}\text { No encryption for Data at } \\
\text { Fiber. }\end{array}$ & Encryption of data at Radio. \\
\hline $\begin{array}{l}\text { No VLAN is configured to } \\
\text { stop broadcast from KSE. }\end{array}$ & $\begin{array}{l}\text { The VLAN is configured to } \\
\text { stop broadcasting from KSE. }\end{array}$ \\
\hline $\begin{array}{l}\text { No load balancing is used for } \\
\text { online clients. }\end{array}$ & $\begin{array}{l}\text { Clustering of the database } \\
\text { will be there. }\end{array}$ \\
\hline $\begin{array}{l}\text { No dual GSM connection is } \\
\text { present. }\end{array}$ & $\begin{array}{l}\text { The dual GSM connection is } \\
\text { there. }\end{array}$ \\
\hline $\begin{array}{l}\text { Automated internet } \\
\text { connection shifting is not } \\
\text { available. }\end{array}$ & $\begin{array}{l}\text { Automatic shifting of } \\
\text { Internet connection. }\end{array}$ \\
\hline
\end{tabular}




\section{CONCLUSION}

This study is conducted with the view to design a flexible infrastructure to accommodate the current requirement by utilizing the technology at the maximum level and needs for potential demand or reconfiguration of facilities employing sound planning principles and infrastructure design of information technology. This study conveys a wide spectrum of Mobile brokerage models is evolving.

In this study the loopholes of the existing infrastructure identified and also solution has been proposed to mitigate the risk in order to strengthen the online trading of brokerage houses. ABC Brokerage House is the pioneer in Online Trading services, Online Trade customers can trade using the Online Trade Software and website.

Mobile Trading System and challenges for mobile commerce solution was discussed in detail. Before switching users from Traditional Trading System to Mobile Trading, the weaknesses of infrastructure, security breaches, and risk factors should be considered carefully. The infrastructure solution should be designed with respect to interoperability, security, scalability, non-repudiation \& of ABC Brokerage House on the behalf of best practices for Mobile Commerce Trading System. The proposed solution is, even though is costly, but secure, reliable and structured infrastructure.

\section{REFERENCES}

[1] Büyüközkan G, "Determining the mobile commerce user requirements using an analytical approach", Computer Standards \& Interfaces, vol. 31 no. 1, pp. 144-152, 2009.

[2] Agarwa A and Bhatawal P, "M Commerce in India: Promise and Problems", International Journal Of Research In Computer And Communication Technology, vol. 4, no. 4, pp. 273-275, 2015.

[3] M. Manju, R. Goyal and P. Gupta, "E-commerce: A Fortune for the Prosperity of Business.", Global Journal of Business Management and Information Technology, vol. 4, no. 1, pp. 25-31, 2014.

[4] C. Looney, L. Jessup and J. Valacich, "Emerging business models for mobile brokerage services", Communications of the ACM, vol. 47, no. 6, pp. 71-77, 2004.

[5] Hew, Jun-Jie. "Hall of fame for mobile commerce and its applications: a bibliometric evaluation of a decade and a half (2000-2015)." Telematics and Informatics, vol. 34, no. 1, pp. 4366, 2017.

[6] Z. Chen, R. Li, X. Chen and H. Xu, "A Survey Study on Consumer Perception of Mobile- Commerce Applications", Procedia Environmental Sciences, vol. 11, pp. 118-124, 2011.

[7] E. Ngai and A. Gunasekaran, "A review for mobile commerce research and applications", Decision Support Systems, vol. 43, no. 1, pp. 3-15, 2007.

[8] A. Chong, "A two-staged SEM-neural network approach to understanding and predicting the determinants of $\mathrm{m}$-commerce adoption", Expert Systems with Applications, vol. 40, no. 4, pp. 1240-1247, 2013.

[9] Z. Huang and M. Benyoucef, "From e-commerce to social commerce: A closer look at the design features", Electronic Commerce Research and Applications, vol. 12, no. 4, pp. 246-259, 2013.

[10] Gupta S. and Vyas A., "Benefits and Drawbacks of M-Commerce in India: A Review.", IJARCCE, vol. 3, no. 4, pp. 6327-6329, 2014.

[11] Jahanshahi, Asghar Afshar, Alireza Mirzaie, and Amin Asadollahi, "Mobile commerce beyond electronic commerce: Issue and challenges.", Asian Journal of Business and Management Sciences, vol. 1, no. 2, pp. 119-129, 2011.
[12] Batra DS \& Juneja D, "M- Commerce in India: Emerging Issues", International Journal of Advanced Research in IT and Engineering, vol. 2, no. 2, pp. 54-65, 2013.

[13] A. Gunasekaran and R. McGaughey, "Mobile commerce: issues and obstacles", International Journal of Business Information Systems, vol. 4, no. 2, pp. 245, 2009.

[14] P. Tarasewich, "Designing mobile commerce applications", Communications of the ACM, vol. 46, no. 12, pp. 57, 2003.

[15] Rask, Morten, and Nikhilesh Dholakia, "Next to the customer's heart and wallet: Frameworks for exploring the emerging mcommerce arena", In American Marketing Association, Conference Proceedings, vol. 12, pp. 372. American Marketing Association, 2001.

[16] M. Frolick and L. Chen, "Assessing M-Commerce Opportunities", Information Systems Management, vol. 21, no. 2, pp. 53-61, 2004.

[17] K. Siau and Z. Shen, "Building customer trust in mobile commerce", Communications of the ACM, vol. 46, no. 4, pp. 9194, 2003.

[18] B. Bahli and Y. Benslimane, "An exploration of wireless computing risks", Information Management \& Computer Security, vol. 12, no. 3, pp. 245-254, 2004.

[19] D. Hoffman, T. Novak and M. Peralta, "Building consumer trust online", Communications of the ACM, vol. 42, no. 4, pp. 80-85, 1999.

[20] Haque, Ahasanul, "Mobile commerce: Customer perception and its prospect on business operation in Malaysia." Journal of American Academy of Business, Cambridge, vol. 4, no. 1/2, pp. 257-262, 2004.

[21] Kesling, Patricia, Richard Michalski, Paul Marko, Craig Wadin, and Stelios Patsiokas. "System and method for mobile commerce." U.S. Patent 9,912,423, issued March 6, 2018.

[22] S. Kumar and C. Zahn, "Mobile communications: evolution and impact on business operations", Technovation, vol. 23, no. 6, pp. 515-520, 2003.

[23] Z. Maamar, "Commerce, e-commerce, and m-commerce", Communications of the ACM, vol. 46, no. 12, p. 251, 2003. 